УДК 378:373.3\%.011.3-051]:[001.89:005.336.2]

https://doi.org/10.52058/2786-4952-2021-5(5)-111-122

Венгловська Олена Анатоліївна кандидат педагогічних наук, доцент кафедри педагогіки та психології, Київський університет імені Бориса Грінченка, вул. Бульварно-Кудрявська, 18/2, м. Київ, 04053, тел.: (097) 424-35-90, e-mail: o.venhlovska@kubg.edu.ua, https://orcid.org/0000-0002-0456-7667

Січкар Алла Дмитрівна кандидат педагогічних наук, доцент кафедри педагогіки та психології, Київський університет імені Бориса Грінченка, вул. Бульварно-Кудрявська, 18/2, м. Київ, 04053, тел.: (050) 166-07-77, e-mail: a.sichkar@kubg.edu.ua, https://orcid.org/0000-0003-0727-5448

Антипін Євген Борисович кандидат педагогічних наук, старший викладач кафедри педагогіки та психології, Київський університет імені Бориса Грінченка, вул. Бульварно-Кудрявська, 18/2, м. Київ, 04053, тел.: (063)872-54-87, e-mail: y.antypin@kubg.edu.ua, https://orcid.org/ 0000-0002-0371-2498

\title{
ФОРМУВАННЯ ПОШУКОВО-ДОСЛІДНИЦЬКИХ УМІНЬ МАЙБУТНІХ ПЕДАГОГІВ У ПЕРЕБІГУ ВИВЧЕННЯ ПЕДАГОГІЧНИХ ДИСЦИПЛІн
}

Анотація. У статті висвітлено результати дослідження щодо особливостей формування пошуково-дослідницьких умінь майбутніх педагогів у перебігу вивчення педагогічних дисциплін. Актуальність дослідження зумовлена зміною підходів до підготовки фахівців відповідно до нових освітніх стандартів та реформ, потребою у формуванні фахівця, здатного до роботи в умовах освітніх змін, генерування ідей, проєктування етапів проведення досліджень, презентації результатів, що мають практичну значущість. Ключовими у цьому контексті $\epsilon$ ті уміння майбутніх педагогів, що забезпечують їхню здатність виконувати трудові функції, що пов'язані із виокремленими характеристиками. Достовірність результатів дослідницького пошуку забезпечувалися комплексом теоретичних та емпіричних методів дослідження, що застосовувалися задля з'ясування теоретичних підходів до розроблення проблеми, висвітлення досвіду роботу закладу вищої освіти щодо формування у здобувачів першого (бакалаврського) рівня вищої освіти пошуково-дослідницьких умінь. За результатами теоретичних студій з'ясовано ступінь розроблення проблеми у педагогічній теорії, сутність поняття «пошуково-дослідницькі уміння», що розглядається як комплекс здатностей особистості виконувати певні дії, спрямовані на визначення освітніх цілей, відбір ресурсів щодо їх реалізації, послідовне та поетапне виконання дій і способів діяльності, інтерпретацію та узагальнення отриманих результатів 
дослідницького пошуку.

Охарактеризовано особливості формування пошуково-дослідницьких умінь здобувачів вищої освіти першого (бакалаврського) рівня вищої освіти у перебігу виконання пошуково-дослідницьких завдань, а саме: індивідуальних та групових проєктів, презентації результатів міні-досліджень, що виконуються ними як у процесі вивчення навчальних дисциплін «Педагогіка» (змістовий модуль «Педагогіка: Педагогіка загальна», Педагогіка: «Педагогіка дошкільна»), «Педагогічне партнерство», так і навчальних практик.

Результати наукової розвідки засвідчили, що пошуково-дослідницькі уміння $\epsilon$ важливою складовою особистісного i професійного зростання майбутніх педагогів із дошкільної та початкової освіти.

Ключові слова: пошуково-дослідницькі уміння, особистісно-професійний розвиток майбутніх педагогів, майбутні педагоги дошкільної та початкової освіти, педагогічні дисципліни, дослідницькі проєкти.

Venhlovska Olena Anatoliivna $\mathrm{PhD}$ in Pedagogy, Associate Professor at the Department of Pedagogy and Psychology, Borys Grinchenko Kyiv University, Bulvarno-Kudriavska St., 18/2, Kyiv, 04053, tel.: (097) 424-35-90, e-mail: o.venhlovska@kubg.edu.ua, https://orcid.org/0000-0002-0456-7667

Sichkar Alla Dmytrivna $\mathrm{PhD}$ in Pedagogy, Associate Professor at the Department of Pedagogy and Psychology, Borys Grinchenko Kyiv University, Bulvarno-Kudriavska St., 18/2, Kyiv, 04053, tel.: (050) 166-07-77, e-mail: a.sichkar@kubg.edu.ua, https://orcid.org/0000-0003-0727-5448

Antypin Yevhen Borysovych $\mathrm{PhD}$ in Pedagogy, Senior Teacher of the Department of Pedagogy and Psychology, Borys Grinchenko Kyiv University, Bulvarno-Kudriavska St., 18/2, Kyiv, 04053,tel.: (063)872-54-87, e-mail: y.antypin@kubg.edu.ua, https//orcid.org/ 0000-0002-0371-2498

\section{FORMATION OF RESEARCH SKILLS OF FUTURE TEACHERS DURING THE STUDY OF PEDAGOGICAL DISCIPLINES}

Abstract. The article highlights the results of research on the peculiarities of the formation of research skills of students of pedagogical specialties during the study of pedagogical disciplines. The relevance of the study is due to changing approaches to training in accordance with new educational standards and reforms, the need to form a specialist capable of working in educational change, generating ideas, designing stages of research, presentation of results of practical significance. The key in this context are the skills of future teachers that ensure their ability to perform job functions that are related to certain characteristics. The reliability of research results was ensured by a set of theoretical and empirical research methods used to clarify theoretical approaches to problem development, highlight the experience of higher 
education institutions in the formation of students', for the first (bachelor's) level of higher education, research skills. The results of theoretical studies clarify the degree of development of the problem in pedagogical theory, the essence of the concept of «research skills», which we consider as a set of abilities to perform certain actions aimed at defining educational goals, selection of resources for their implementation, consistent and gradual implementation of actions and methods of activity, interpretation, and generalization of the results of research.

The peculiarities of formation of research skills of students for the first (bachelor's) level of higher education during research tasks, namely: individual and group projects, presentation of mini-research results performed by them as in the study of disciplines «Pedagogy» (Content modules «Pedagogy: General Pedagogy», «Pedagogy: Preschool Pedagogy»), «Pedagogical Partnership», and the tasks of educational practices.

The results of scientific research showed that research skills are an important component of personal and professional growth of future preschool and primary school teachers.

Keywords: research skills, personal and professional development of future teachers, future preschool and primary school teachers, pedagogical disciplines, research projects.

Постановка проблеми. Підготовка майбутніх педагогів в умовах реалізації нових освітніх стандартів і реформи «Нова українська школа» актуалізує наукову проблему пошуку змісту та технологій особистісного i професійного розвитку фахівців, здатних навчатися впродовж життя.

На часі вибудовування нових освітніх практик підготовки вчителя закладу загальної середньої освіти, вихователя закладу дошкільної освіти відповідно до нових стандартів - Професійного стандарту за професіями «Вчитель початкових класів закладу загальної середньої освіти», «Вчитель закладу загальної середньої освіти», «Вчитель початкової освіти (з дипломом молодшого спеціаліста)» (2020) [1], Професійного стандарту «Вихователь закладу дошкільної освіти» (2021) [2]. Насамперед варто виокремити вартісну для особистісно-професійного становлення педагога компетентність, зокрема: «здатність до генерування нових ідей, виявлення та розв'язання проблем, ініціативності» $[1$, с. 6].

У руслі зазначеної наукової проблеми виокремлено доцільні методологічні підходи: особистісно-орієнтований, діяльнісний, інтегрований. Означені положення $є$ ключовими у вибудовуванні освітнього процесу, відбору змісту та технологій навчання, визначенні системи стимулів, що спрямовані на формування пошуково-дослідницьких умінь майбутніх фахівців із дошкільної та початкової освіти.

Аналіз останніх досліджень i публікацій. Студіювання джерел із означеної проблеми уможливило з'ясування стану іiі розробленості в педагогічній теорії. Встановлено, що різні аспекти формування у майбутніх 
Журнал«Герспективита іновації наукиљ

(Серія «Гедагогіка»), Серія«ГТихологія», Серія «Медицина»

№5(5) 2021

педагогів пошуково-дослідницьких умінь знайшли відображення у працях зарубіжних та українських учених. Так, окремі питання проблеми формування виокремлених умінь у працях зарубіжних дослідників розглядаються у сув'язі із навичками XXI століття (Д. Уерц (D. Uerł, M. Волман (M. Volman), M. Крал (M. Kral)) [3], у перебігу виконання майбутніми педагогами завдань навчальних практик (А. Г. Брандт (А. G. Brandt), M. де С. Гобольд (M.de S. Hobold)) [4], залучення студентів до розв’язання дослідницьких завдань (С.M.Д. Токеро (C.M.D. Toquero)) [5].

У науковому полі України питання формування дослідницької культури педагога, як складової його професійного зростання досліджував С. Гончаренко [6]. У контексті реалізації мети пропонованої розвідки значущими $є$ узагальнення щодо формування пошуково-дослідницьких умінь майбутніх педагогів як складової їхнього особистісно-професійного саморозвитку (Г. Іванюк, О. Венгловська, Є. Антипін, Я. Вовчок) [7], визначення сутності поняття «дослідницька компетентність» майбутніх педагогів та умови ऑii формування (С. Омеляненко) [8], формування дослідницьких умінь майбутніх учителів початкової школи (К. Степанюк) [9].

Вивчення наукових праць засвідчило, що попри наявну джерельну базу проблеми наукового пошуку питання формування пошуково-дослідницьких умінь майбутніх педагогів у перебігу вивчення педагогічних дисциплін не знайшло належного висвітлення, що й зумовило вибір тематики пропонованої статті.

Мета статті - висвітлити особливості формування пошуководослідницьких умінь майбутніх педагогів у перебігу виконання дослідницьких завдань під час вивчення педагогічних дисциплін.

Для реалізації мети дослідження використано комплекс методів наукового дослідження, зокрема: теоретичні (аналіз, синтез, узагальнення) застосовувалися для відбору та систематизації джерел із проблеми наукового пошуку, з'ясування стану проблеми у педагогічній теорії, сутності поняття «пошуково-дослідницькі уміння майбутніх педагогів»; емпіричні методи опитування здобувачів першого (бакалаврського) рівня вищої освіти задля 3’ясування їхніх потреб у формуванні пошуково-дослідницьких умінь, вивчення результатів дослідницьких проєктів студентів задля дослідження здатностей майбутніх педагогів вирішувати дослідницькі завдання.

Виклад основного матеріалу. Реалізація нових освітніх стандартів в Україні зумовлює зміну вектору у підготовці майбутніх педагогів - від пріоритету знань (інформаційного забезпечення), до першорядності суб'єктності студента в навчально-пошуковій діяльності, формування здатностей застосовувати здобуті в різноманітних джерелах знання. Підготовка майбутніх педагогів до виконання трудових функцій актуалізує проблему формування їхніх здатностей та готовності до виявлення та вирішення проблем, що пов’язані з освітою дітей дошкільного та молодшого шкільного віку, пошуку джерел та критичного оцінювання інформації, роботи в команді, 
застосування методів наукового пізнання в освітньому процесі.

У цьому контексті постає потреба у зміні підходів до викладання навчальних дисциплін (впровадженні інноваційних, особистісно орієнтованих, проєктивних технологій навчання), ролі студента: від пасивного споживача інформації - до активного учасника отримання нових знань; функцій викладача: від ретранслятора провідних ідей - до виконання функцій фасилітатора, який здійснює супровід становлення майбутнього фахівця. Значущими для розкриття проблематики пропонованої розвідки $\epsilon$ виосновування Г. Іванюк про підготовку майбутніх педагогів 3 урахуванням діяльнісного підходу. У статті «Нова стратегія професійно-педагогічної освіти: Європейський вимір» науковиця зазначає: «Діяльнісний підхід є визначальним у навчанні (на різних ступенях i рівнях) здобуття освіти, зумовлює утвердження реального життя і досвіду людської діяльності. Відтак важливим $є$ навчання в діяльності, що грунтується на вартісному для молодого покоління національному й інноваційному досвіді. В діяльності особистість реалізує як власні (індивідуальні), так і суспільно значущі сенси. Знання співвідносяться 3 уміннями: діяти, бути, жити» [10, С. 22].

Відтак, у перебігу навчання за освітньо-професійними програмами 012.00.01 Дошкільна освіта, 013.00.01 Початкова освіта у Київському університеті імені Бориса Грінченка майбутні фахівці набувають умінь, що $є$ значущими у фаховому зростанні. Обов'язковим компонентом названих освітньо-професійних програм $\epsilon$ навчальні дисципліни «Педагогіка», «Педагогічне партнерство», що спрямовані на формування загальних та фахових компетентностей здобувачів вищої освіти. 3-поміж низки обов'язкових практичних результатів вивчення навчальних дисциплін варто виокремити пошуково-дослідницькі уміння майбутніх фахівців.

Зазначимо, що у пропонованій розвідці пошуково-дослідницькі уміння розглядаємо як комплекс здатностей майбутніх педагогів виконувати дії, що спрямовані на визначення освітніх цілей, проєктування етапів проведення досліджень, відбір ресурсів, необхідних для їх реалізації, а також інтерпретацію та узагальнення отриманих результатів та впровадження їх в освітню практику.

Результати опитування студентів першого курсу спеціальностей 012 «Дошкільна освіта», 013 «Початкова освіта», що було проведене у Педагогічному інституті Київського університету імені Бориса Грінченка, сприяли з'ясуванню потреби у формуванні здобувачів вищої освіти пошуководослідницьких умінь. Узагальнення результатів відповідей респондентів засвідчили, що студенти відчувають труднощі у здійсненні добору засобів для пошуку інформації, що пов'язана із проблематикою дослідницького поля, критичного аналізу різних груп джерел (26\%). Значний відсоток студентів на початку навчання потребували допомоги у визначенні стратегій, проєктуванні етапів виконання завдань пошуково-дослідницького спрямування, розподілі обов’язків під час командної роботи (32\%), адаптації та продукуванні нових 
Журнал«Герспективита іновації наукиљ

(Серія«Гедагогіка»), Серія«ГТихологія», Серія «Медицина»

№5(5) 2021

знань для власного особистісного та професійного зростання (42\%).

Отримані результати підтвердили потребу у розробленні тематики лекцій, завдань семінарських, практичних занять, самостійної роботи навчальних дисциплін педагогічного блоку, що були б спрямовані на формування у студентів педагогічних спеціальностей пошуково-дослідницьких умінь сутність яких полягає у здатності:

- добирати засоби для пошуку інформації та вирішення дослідницького завдання;

- працювати з різними групами джерел;

- проєктувати етапи виконання пошуково-дослідницьких завдань;

- розробляти стратегію для ефективного вирішення дослідницького завдання;

- інтерпретувати результати емпіричних досліджень;

- продукувати нові знання задля їх використання у власній професійній діяльності;

- створювати й презентувати власні освітні продукти;

- впроваджувати результати пошуково-дослідницької діяльності в освітній процес закладів дошкільної та загальної середньої освіти (початкова школа).

Задля визначення власного прогресу у формуванні пошуководослідницьких умінь студентам пропонується картка їх самооцінювання (таблиця 1). У картці студенти фіксують власні результати, яких вони досягли під час виконання дослідницьких завдань.

Таблиия 1

\section{Картка самооцінювання рівня сформованості} пошуково-дослідницьких умінь

\begin{tabular}{|c|c|}
\hline Мій прогрес & Характеристика пошуково-дослідницьких умінь \\
\hline Новачок & $\begin{array}{l}- \text { приймаю проблему наукового пошуку; } \\
-\quad \text { добираю засоби для пошуку інформації за } \\
\text { допомогою сторонніх осіб; } \\
- \text { працюю } 3 \text { різними групами джерел час від } \\
\text { часу; } \\
\text { - послуговуюсь розробленими алгоритмами } \\
\text { пошуку; } \\
-\quad \text { є частиною команди, яка працює над } \\
\text { вирішенням пошуково-дослідницького завдання; } \\
\text { - підтримую ідеї інших щодо створення та } \\
\text { вибору форми презентації кінцевого продукту }\end{array}$ \\
\hline Дослідник & $\begin{array}{ll}\text { - } & \text { маю здатність до аналітичної діяльності; } \\
\text { - } & \text { проєктую етапи виконання дослідження; }\end{array}$ \\
\hline
\end{tabular}




\begin{tabular}{|c|c|}
\hline & 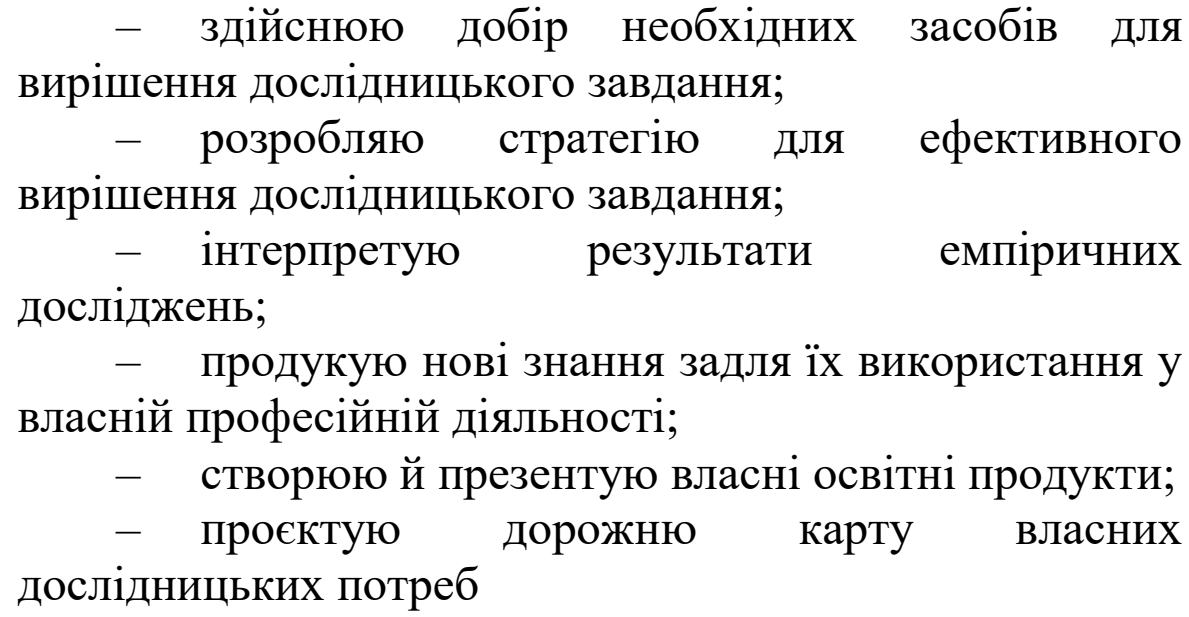 \\
\hline Інноватор & 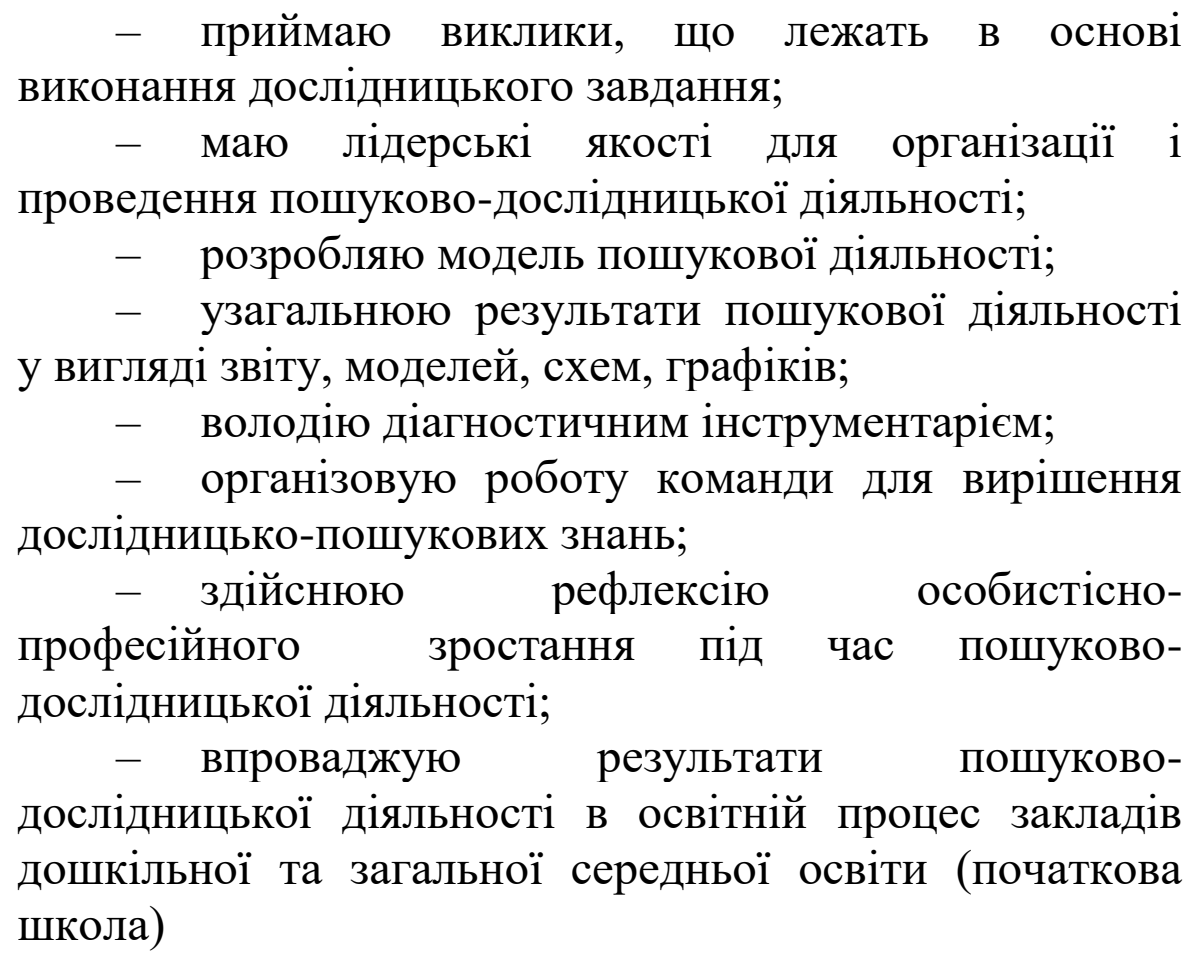 \\
\hline
\end{tabular}

Варто зауважити, що у картці самооцінювання студенти фіксують результати по завершенню вивчення змістових модулів названих навчальних дисциплін. Наведемо приклади завдань, що спрямовані на формування пошуково-дослідницьких умінь студентів, які вони виконують у перебігу вивчення навчальних дисциплін «Педагогіка» (змістовий модуль «Педагогіка: Педагогіка загальна», «Педагогіка: Дошкільна педагогіка») та «Педагогічне партнерство». Варто зазначити, що тематика пошуково-дослідницьких завдань формувалася 3 урахуванням нової освітньої стратегії підготовки фахівців, що реалізується у Київському університеті імені Бориса Грінченка, концептуальних основ навчання на дослідженнях, а також результатах вивчення потреб здобувачів вищої освіти.

До прикладу, під час вивчення теоретичного матеріалу змістових модулів 
Журнал«Герспективитаінновації науки»

(Серія «Гедагогіка», Серія«Гиихологія», Серія«Медицина»

№5(5) 2021

інтегрованої дисципліни «Педагогіка» студентам пропонується завдання, що вимагає від них критичного аналізу змісту джерел, їх узагальнення та інтерпретації. Так, за результатами опрацювання теми «Становлення та розвиток педагогіки в історико-педагогічній ретроспективі» студентам пропонувалися питання дискусійного характеру: «За результатами опрацювання теоретичних джерел, обгрунтувати визначення поняття педагогіки, що найповніше розкриває іiі сутність». Під час опрацювання теми «Освіта людини як соціокультурний процес» майбутні педагоги висловлюють власні міркування щодо важливості принципу дитиноцентризму в організації освітнього процесу у закладах дошкільної та загальної середньої освіти (початкова школа) тощо. Студіюючи проблему дитинства - як соціальнопедагогічного явища - вчаться визначати та обгрунтовувати чинники, що впливають на формування ціннісних орієнтацій дітей дошкільного віку/учнів початкової школи.

У перебігу обговорення проблемних запитань студенти набувають умінь вести дискусію на актуальні проблеми дитинства, виокремлювати позитивні чинники, що впливають на освіту людини, визначати можливі ризики, висловлювати власне бачення щодо можливих шляхів впровадження досягнень педагогічної науки у практику закладів дошкільної освіти та початкових шкіл. Окрім того, набувають досвіду роботи 3 джерелами, відбору тих, що в повній мірі відповідають завданням дослідницького пошуку, отримують нове знання, що є значущим для їхнього особистісного і професійного розвитку.

Практичну спрямованість щодо формування пошуково-дослідницьких умінь студентів мають завдання, що виконуються ними у перебігу семінарських та практичних занять. Так, під час практичного заняття 3 теми «Актуальні проблеми освіти людини в педагогічній думці: історикопедагогічна ретроспектива», що вивчається у курсі інтегрованої навчальної дисципліни «Педагогіка» майбутні педагоги за результатами вивчення різних груп історико-освітніх джерел створюють колажі, в яких візуалізують особливості освіти людини на різних історико-педагогічних етапах, презентують внесок педагогічних персоналій у становлення i розвиток дошкільної та початкової освіти.

Для того, щоб виконати пропоновані завдання студенти об'єднуються у мікрогрупи, розподіляють обов'язки в команді, планують етапи проведення міні-досліджень, здійснюють пошук необхідних джерел, аналізують та узагальнюють отриману інформацію, обгрунтовують шляхи адаптації прогресивних ідей педагогів минулого в сучасну освітню практику, планують форму презентації освітнього продукту. Такий підхід сприяв формуванню здатностей студентів педагогічних спеціальностей проводити теоретичне дослідження, результати якого є значущими для їхнього особистісного та професійного зростання.

Важливо, що зміст завдань семінарських i практичних занять взаємопов'язаний із тематикою досліджень, які здобувачі вищої освіти 
виконують під час проходження практик. Результати таких досліджень обговорюються під час аудиторних занять. Наприклад, одним із завдань, яке студенти першого курсу виконують під час навчальної практики є дослідження особливостей здійснення психолого-педагогічного супроводу дітей у різних типах закладів дошкільної освіти та початкових школах. 3 цією метою вони вивчають організаційні умови розвивального середовища закладів освіти різного типу, досліджують особливості реалізації педагогами принципу дитиноцентризму, функціонального та змістового наповнення навчальних осередків в початкових школах та осередків за інтересами у закладах дошкільної освіти. Результати досліджень заносяться до спеціальних таблиць. Під час практичних занять змістового модуля «Педагогіка: Педагогіка дошкільна» студенти обговорюють та аналізують отримані результати, визначають позитивні аспекти й виокремлюють коло питань, що потребують удосконалення, визначають можливі шляхи покращення розвивальної діяльності дітей дошкільного та молодшого шкільного віку.

У перебігу вивчення навчальної дисципліни «Педагогічне партнерство» студенти спеціальності 012 «Дошкільна освіта», котрі навчаються за скороченою програмою підготовки, у перебігу практичних, лабораторних занять здійснюють підбірку чи/або розробляють авторські ігри та вправи, що можуть використовувати вихователі для налагодження взаємодії між дітьми, проєктують структуру та зміст методичного кейсу педагогічного партнерства ЗДО з батьками, розробляють орієнтовні плани співпраці ЗДО з культурнопросвітницькими установами (бібліотека, лялькові театри, музеї тощо). Важливо, що власні напрацювання, отримані під час навчальних занять, студенти впроваджують та апробують під час практики, аналізують їх ефективність, вносять корективи. Тим самим розширюють простір для формування власних пошуково-дослідницьких умінь.

Варто зауважити, що зміст пропонованих завдань відповідає стратегії навчання на дослідженнях. Важливо, що означена стратегія має чітко визначені компоненти (методологічний, мотиваційно-ціннісний, процесуальнотехнологічний, рефлексивний, за Г. Іванюк) [11], дотримання яких в сукупності розв’язує завдання щодо формуються пошуково-дослідницьких умінь майбутніх фахівців із дошкільної та початкової освіти. А відтак, викладачі у співпраці зі студентами, продумують та обгрунтовують концепцію виконання завдань, формують зміст із урахуванням особистісної мотивації та професійних цінностей майбутніх фахівців, продумують шляхи упровадження авторських освітніх продуктів i, що важливо, кожен студент здійснює рефлексію щодо поступу в особистісному сенсі та професійному вивищенні, визначає подальші кроки свого становлення.

На завершальному етапі вивчення змістових модулів навчальної дисципліни «Педагогіка», «Педагогічне партнерство» проводилося повторне опитування студентів. Результати опитування студентів та вивчення карток самооцінювання засвідчили позитивну динаміку в усвідомленні студентами 
потреби у формуванні власних пошуково-дослідницьких умінь. Переважна більшість респондентів (83\%) зазначили про те, що дослідницькі завдання, які вони розв’язували під час вивчення навчальних дисциплін, сприяли розкриттю особистісних резервів, здатностей та способів діяльності у визначені власних освітніх цілей, дослідженні вікових особливостей дітей дошкільного та молодшого шкільного віку, проєктуванні їхньої індивідуальної освітньої траєкторії. Окрім того, майбутні педагоги продемонстрували здатність до організації роботи команд для вирішення дослідницько-пошукових завдань, інтерпретації результатів емпіричних досліджень, здійснення рефлексії власних дослідницьких потреб.

Таким чином, застосування у перебігу вивчення навчальних дисциплін педагогічного спрямування завдань, що передбачають формування у студентів пошуково-дослідницьких умінь, здатності та готовності до їх застосування у практичній діяльності розв'язує питання щодо формування у майбутніх педагогів трудових функцій, що визначені професійними стандартами та зумовлені суспільними викликами.

Висновки. За результатами студіювання проблеми формування пошуково-дослідницьких умінь майбутніх педагогів у перебігу вивчення педагогічних дисциплін доходимо висновку про те, що сучасна освіта потребує фахівця, здатного організувати освітній процес у закладі дошкільної, загальної середньої освіти (початкова школа) на дослідницькій основі, що відповідає концептуальним положенням нової стратегії підготовки фахівців, що реалізується у контексті положень Нової української школи, Базового компоненту дошкільної освіти. У цьому сенсі значущими для майбутнього фахівця є особистісні та професійні сенси, що фокусують його увагу на вмінні бачити питання, що потребують професійного вирішення, здатності до вивчення потреб здобувачів освіти та визначення шляхів реалізації їхньої індивідуальної освітньої траєкторії, розроблення освітніх продуктів та їх упровадження в освітню практику.

Проведений науковий пошук засвідчує, що дослідницько-пошукові уміння $\epsilon$ важливою складовою особистісно-професійного розвитку майбутніх фахівців iз дошкільної та початкової освіти. Відтак, постає потреба в удосконаленні змістово-методичного забезпечення навчальних дисциплін педагогічного спрямування з урахуванням суспільних запитів, освітніх інновацій, особистих намірів здобувачів вищої освіти. Сформованість у студентів досліджуваних умінь сприятиме їхньому особистісному i професійному розвитку та саморозвитку, і як результат, підвищить якість освітнього процесу у закладах освіти.

Зазначимо, що попри системне висвітлення проблеми наукового пошуку потребують подальшої наукової дискусії питання формування пошуководослідницьких умінь майбутніх фахівців у перебігу організації різних видів позааудиторної роботи. 


\section{Лimepamypa:}

1. Про затвердження професійного стандарту за професіями «Вчитель початкових класів закладу загальної середньої освіти», «Вчитель закладу загальної середньої освіти», «Вчитель початкової освіти (з дипломом молодшого спеціаліста)»: Наказ Міністерства розвитку економіки, торгівлі та сільського господарства України від 23.12.2020 № 2736 . URL: https://www.me.gov.ua/Documents/Detail?lang=uk-UA\&id=22469103-4e36-4d41-b1bf288338b3c7fa\&title=RestrProfesiinikhStandartiv (дата звернення: 20.11.2021).

2. Про затвердження професійного стандарту «Вихователь закладу дошкільної освіти»: Наказ Міністерства розвитку економіки, торгівлі та сільського господарства України від 19 жовтня 2021 року № 755-21. URL: https://mon.gov.ua/ua/npa/pro-zatverdzhennya-profesijnogostandartu-vihovatel-zakladu-doshkilnoyi-osviti (дата звернення: 20.11.2021).

3. Uerz D., Volman M., Kral M. Teacher educators' competences in fostering student teachers' proficiency in teaching and learning with technology: An overview of relevant research literature. Teaching and Teacher Education. Volume 70, February 2018, pp. 12-23.

4. Brandt, A. G., Hobold, M. de S. A Prática como componente curricular na disciplina pesquisa e processos educativos do curso de pedagogia: Um diferencial na relação entre pesquisa, teoria e prática. Educ. Form., [S. l.], v. 4, n. 11, 2019. Pp. 142-160, DOI: 10.25053/redufor.v4i11.319.

5. Toquero, C.M.D. «Real-world»: preservice teachers' research competence and research difficulties in action research». Journal of Applied Research in Higher Education, Vol. 13 No. 1, 2021. Pp. 126-148. https://doi.org/10.1108/JARHE-03-2019-0060.

6. Гончаренко С.У. Педагогічні дослідження: Методологічні поради молодим науковцям. Київ-Вінниця: ДОВ «Вінниця», 2008. 278 с.

7. Ivaniuk, H., Venhlovska, O., Antypin, Y., Vovchok, Y. Self-Development as a Factor in the Professional Growth of Future Teachers. Journal of History Culture and Art Research, 9(4), 2020. Pp. 77-86. doi: http://dx.doi.org/10.7596/taksad.v9i4.2873.

8. Омельяненко С.В. Педагогічні умови формування дослідницької компетентності майбутніх педагогів. URL: http://dspace.cuspu.edu.ua/jspui/bitstream/123456789/2687/1/\% D0\%9F\%D0\%B5\%D0\%B4\%D0\%B0\%D0\%B3\%D0\%BE\%D0\%B3\%D1\%96\%D1\%87\%D0\%BD $\% \mathrm{D} 1 \% 96 \% 20 \% \mathrm{D} 1 \% 83 \% \mathrm{D} 0 \% \mathrm{BC} \% \mathrm{D} 0 \% \mathrm{BE} \% \mathrm{D} 0 \% \mathrm{~B} 2 \% \mathrm{D} 0 \% \mathrm{~B} 8 \% 20 \% \mathrm{D} 1 \% 84 \% \mathrm{D} 0 \% \mathrm{BE} \% \mathrm{D} 1 \% 80$ $\% \mathrm{D} 0 \% \mathrm{BC} \% \mathrm{D} 1 \% 83 \% \mathrm{D} 0 \% \mathrm{~B} 2 \% \mathrm{D} 0 \% \mathrm{~B} 0 \% \mathrm{D} 0 \% \mathrm{BD} \% \mathrm{D} 0 \% \mathrm{BD} \% \mathrm{D} 1 \% 8 \mathrm{~F} \% 20 \% \mathrm{D} 0 \% \mathrm{~B} 4 \% \mathrm{D} 0 \% \mathrm{BE} \%$ D1\%81\%D0\%BB\%D1\%96\%D0\%B4\%D0\%BD\%D0\%B8\%D1\%86\%D1\%8C\%D0\%BA\%D0\%B E\%D1\%97\%20\%D0\%BA\%D0\%BE\%D0\%BC\%D0\%BF\%D0\%B5\%D1\%82\%D0\%B5\%D0\%BD $\% \mathrm{D} 1 \% 82 \% \mathrm{D} 0 \% \mathrm{BD} \% \mathrm{D} 0 \% \mathrm{BE} \% \mathrm{D} 1 \% 81 \% \mathrm{D} 1 \% 82 \% \mathrm{D} 1 \% 96 \% 20 \% \mathrm{D} 0 \% \mathrm{BC} \% \mathrm{D} 0 \% \mathrm{~B} 0 \% \mathrm{D} 0 \% \mathrm{~B} 9 \% \mathrm{D}$ 0\%B1\%D1\%83\%D1\%82\%D0\%BD\%D1\%96\%D1\%85\%20\%D0\%BF\%D0\%B5\%D0\%B4\%D0\% B0\%D0\%B3\%D0\%BE\%D0\%B3\%D1\%96\%D0\%B2.pdf (дата звернення 23.11.2021).

9. Степанюк К. Формування дослідницьких умінь майбутніх учителів початкової школи як проблема педагогічної науки. Наукові записки БДПУ. Серія: Педагогічні науки. Вип. 3, 2018. С. 292-300.

10. Іванюк Г. І. Нова стратегія професійно-педагогічної освіти: європейський вимір. Педагогічний процес: теорія та практика, 4(59), 2017. С. 21-26.

11. Іванюк, Г. І. Підготовка фахівців із дошкільної освіти: навчання на дослідженнях. Актуальні проблеми та перспективи розвитку дошкільної освіти і професійної підготовки педагогічних кадрів у контексті євроінтеграчійних процесів: Матеріали Міжнародної науково-практичної конференції, 12-13 травня, 2016 року, м. Чернівці. с. 33-37.

\section{References:}

1. Pro zatverdzhennia profesiinoho standartu za profesiiamy «Vchytel pochatkovykh klasiv zakladu zahalnoi serednoi osvity», «Vchytel zakladu zahalnoi serednoi osvity», «Vchytel pochatkovoi osvity (z dyplomom molodshoho spetsialista)»: Nakaz Ministerstva rozvytku ekonomiky, torhivli ta silskoho hospodarstva Ukrainy vid 23.12.2020 № 2736 [On approval of the 
professional standard for the professions «Primary school teacher of general secondary education», «Teacher of general secondary education», «Primary teacher (with a diploma of junior specialist)»: Order of the Ministry of Economy, Trade and Agriculture of Ukraine from 23.12.2020 № 2736]. (n.d.). me.gov.иа. Retrieved from https://www.me.gov.ua/Documents/Detail?lang=uk-UA\&id= 22469103-4e36-4d41-b1bf-288338b3c7fa\&title=RestrProfesiinikhStandartiv [in Ukrainian].

2. Pro zatverdzhennia profesiinoho standartu «Vykhovatel zakladu doshkilnoi osvity»: Nakaz Ministerstva rozvytku ekonomiky, torhivli ta silskoho hospodarstva Ukrainy vid 19 zhovtnia 2021 roku № 755-21 [On approval of the professional standard «Preschool teacher»: Order of the Ministry of Economic Development, Trade and Agriculture of Ukraine of October 19, 2021 № 755-21]. (n.d.). mon.gov.ua. Retrieved from https://mon.gov.ua/ua/npa/pro-zatverdzhennyaprofesijnogo-standartu-vihovatel-zakladu-doshkilnoyi-osviti [in Ukrainian].

3. Uerz, D., Volman, M. \& Kral, M. (2018). Teacher educators' competences in fostering student teachers' proficiency in teaching and learning with technology: An overview of relevant research literature. Teaching and Teacher Education, 70, 12-23.

4. Brandt, A. G., \& Hobold, M. de S. A (2019). Prática como componente curricular na disciplina pesquisa e processos educativos do curso de pedagogia: Um diferencial na relação entre pesquisa, teoria e prática. Educ. Form., [S. l.], 4, 11, 142-160. DOI: 10.25053/redufor.v4i11.319.

5. Toquero, C.M.D. (2021). «Real-world:» preservice teachers' research competence and research difficulties in action research». Journal of Applied Research in Higher Education, 13, 1, 126-148. https://doi.org/10.1108/JARHE-03-2019-0060.

6. Honcharenko, S.U. (2008). Pedahohichni doslidzhennia: Metodolohichni porady molodym naukovtsiam [Pedagogical research: Methodological advice for young scientists]. Kyiv-Vinnytsia: DOV «Vinnytsia» [in Ukrainian].

7. Ivaniuk, H., Venhlovska, O., Antypin, Y., \& Vovchok, Y. (2020). Self-Development as a Factor in the Professional Growth of Future Teachers. Journal of History Culture and Art Research, 9(4), 77-86. doi: http://dx.doi.org/10.7596/taksad.v9i4.2873.

8. Omelianenko, S.V. Pedahohichni umovy formuvannia doslidnytskoi kompetentnosti maibutnikh pedahohiv [Pedagogical conditions for the formation of research competence of future teachers]. Retrieved from http://dspace.cuspu.edu.ua/jspui/bitstream/123456789/2687/1/\%D0\% 9F\%D0\%B5\%D0\%B4\%D0\%B0\%D0\%B3\%D0\%BE\%D0\%B3\%D1\%96\%D1\%87\%D0\%BD\%D1 $\% 96 \% 20 \% \mathrm{D} 1 \% 83 \% \mathrm{D} 0 \% \mathrm{BC} \% \mathrm{D} 0 \% \mathrm{BE} \% \mathrm{D} 0 \% \mathrm{~B} 2 \% \mathrm{D} 0 \% \mathrm{~B} 8 \% 20 \% \mathrm{D} 1 \% 84 \% \mathrm{D} 0 \% \mathrm{BE} \% \mathrm{D} 1 \% 80 \% \mathrm{D} 0$ $\% \mathrm{BC} \% \mathrm{D} 1 \% 83 \% \mathrm{D} 0 \% \mathrm{~B} 2 \% \mathrm{D} 0 \% \mathrm{~B} 0 \% \mathrm{D} 0 \% \mathrm{BD} \% \mathrm{D} 0 \% \mathrm{BD} \% \mathrm{D} 1 \% 8 \mathrm{~F} \% 20 \% \mathrm{D} 0 \% \mathrm{~B} 4 \% \mathrm{D} 0 \% \mathrm{BE} \% \mathrm{D} 1 \%$ 81\%D0\%BB\%D1\%96\%D0\%B4\%D0\%BD\%D0\%B8\%D1\%86\%D1\%8C\%D0\%BA\%D0\%BE\%D $1 \% 97 \% 20 \% \mathrm{D} 0 \% \mathrm{BA} \% \mathrm{D} 0 \% \mathrm{BE} \% \mathrm{D} 0 \% \mathrm{BC} \% \mathrm{D} 0 \% \mathrm{BF} \% \mathrm{D} 0 \% \mathrm{~B} 5 \% \mathrm{D} 1 \% 82 \% \mathrm{D} 0 \% \mathrm{~B} 5 \% \mathrm{D} 0 \% \mathrm{BD} \% \mathrm{D} 1$ $\% 82 \% \mathrm{D} 0 \% \mathrm{BD} \% \mathrm{D} 0 \% \mathrm{BE} \% \mathrm{D} 1 \% 81 \% \mathrm{D} 1 \% 82 \% \mathrm{D} 1 \% 96 \% 20 \% \mathrm{D} 0 \% \mathrm{BC} \% \mathrm{D} 0 \% \mathrm{~B} 0 \% \mathrm{D} 0 \% \mathrm{~B} 9 \% \mathrm{D} 0 \% \mathrm{~B}$ 1\%D1\%83\%D1\%82\%D0\%BD\%D1\%96\%D1\%85\%20\%D0\%BF\%D0\%B5\%D0\%B4\%D0\%B0\% D0\%B3\%D0\%BE\%D0\%B3\%D1\%96\%D0\%B2.pdf [in Ukrainian].

9. Stepaniuk, K. (2018). Formuvannia doslidnytskykh umin maibutnikh uchyteliv pochatkovoi shkoly yak problema pedahohichnoi nauky [Formation of research skills of future primary school teachers as a problem of pedagogical science]. Naukovi zapysky BDPU. Seriia: Pedahohichni nauky, 3, 292-300 [in Ukrainian].

10. Ivaniuk, H. I. (2017). Nova stratehiia profesiino-pedahohichnoi osvity: yevropeiskyi vymir [A new strategy for vocational education: the European dimension]. Pedahohichnyi protses: teoriia ta praktyka, 4(59), 21-26 [in Ukrainian].

11. Ivaniuk, H. I. (2016). Pidhotovka fakhivtsiv iz doshkilnoi osvity: navchannia na doslidzhenniakh [Training of specialists in preschool education: training in research]. Aktualni problemy ta perspektyvy rozvytku doshkilnoi osvity i profesiinoi pidhotovky pedahohichnykh kadriv $u$ konteksti yevrointehratsiinykh protsesiv [Current problems and prospects for the development of preschool education and professional training of teachers in the context of European integration processes]: Materialy Mizhnarodnoi naukovo-praktychnoi konferentsii, 12-13 travnia, 2016 roku, m. Chernivtsi, 33-37 [in Ukrainian]. 